\title{
Dye-sensitized solar cells with natural dyes extracted from plant seeds
}

\author{
Hatem S. El-Ghamri ${ }^{1}$, TAher M. El-Agez ${ }^{1}$, Sofyan A. TAyA ${ }^{1 *}$, \\ MONZIR S. ABDEL-LATIF ${ }^{2}$, AMAL Y. BATNiJi ${ }^{1}$ \\ ${ }^{1}$ Physics Department, Islamic University of Gaza, Gaza, Palestinian Authority \\ ${ }^{2}$ Chemistry Department, Islamic University of Gaza, Gaza, Palestinian Authority
}

\begin{abstract}
The application of natural dyes extracted from plant seeds in the fabrication of dye-sensitized solar cells (DSSCs) has been explored. Ten dyes were extracted from different plant seeds and used as sensitizers for DSSCs. The dyes were characterized using UV-Vis spectrophotometry. DSSCs were prepared using $\mathrm{TiO}_{2}$ and $\mathrm{ZnO}$ nanostructured mesoporous films. The highest conversion efficiency of $0.875 \%$ was obtained with an allium cepa (onion) extract-sensitized $\mathrm{TiO}_{2}$ solar cell. The process of $\mathrm{TiO}_{2}$-film sintering was studied and it was found that the sintering procedure significantly affects the response of the cell. The short circuit current of the DSSC was found to be considerably enhanced when the $\mathrm{TiO}_{2}$ semiconducting layer was sintered gradually.
\end{abstract}

Keywords: dye sensitized solar cell; $\mathrm{TiO}_{2}$; ZnO; natural dyes; plant seeds

(C) Wroclaw University of Technology.

\section{Introduction}

The dye-sensitized solar cell (DSSC) is one of the photochemical electric cells, often called "Grätzel cell" [1]. It is a very promising candidate for next-generation solar cells due to the prospects of low cost and high efficiency [2-9]. A DSSC consists of a porous wide band gap semiconductor thin film layer like $\left(\mathrm{TiO}_{2}, \mathrm{ZnO}, \mathrm{SnO}_{2}, \mathrm{Nb}_{2} \mathrm{O}_{5}\right)$ coated on a fluorine-doped tin oxide (FTO) photoanode electrode, a dye, a platinum (Pt) thin film counter electrode and an electrolyte normally containing $\mathrm{I}^{-} / \mathrm{I}_{3}^{-}$redox couple. The most characteristic feature of the DSSC relative to other types of solar cells is the use of a dye. It is well known that the energy gap size of the applied semiconductors determines the absorption frequency of light in solar cells. An important purpose for using dyes in the DSSC is to expand the absorption spectra to the visible light. The absorption spectra of DSSCs are determined by the combination of the nanocrystalline porous semiconductor and the dye. In this context,

*E-mail: staya@iugaza.edu.ps investigating these two crucial factors is very important to understand the significant role they play in absorbing sunlight and transforming it into electric energy [2, 3].

Several metal complexes and organic dyes have been synthesized and used as sensitizers including porphyrins [4], platinum complexes [7], and fluorescent dyes [8]. Among these, Ru-based complexes sensitizers have been widely used because they have better efficiency compared to the other ones, and high durability. However, these advantages are offset by their high cost, their complicated synthetic routes, and the tendency to undergo degradation in the presence of water [9].

The increasing interest in natural dyes is attributed to their high availability, harmless, complete biodegradation, low cost, and simple and safe extraction from plants without requiring complex synthetic procedures. Therefore, the investigation of DSSCs using natural dyes is extremely important for practical applications. In fact, natural dyes have been used in DSSCs exhibiting moderate energy conversion efficiency [10-19] For instance, natural chlorophyll dyes have exhibited 
energy conversion efficiencies over $4 \%$ [20, 21]. However, other natural dyes have not yielded energy conversion efficiencies over $2 \%$ [22].

Although most of the reported works on DSSCs are based on $\mathrm{TiO}_{2}$ porous thin films, various structures of $\mathrm{ZnO}$ are also being used for DSSC fabrication. The advantages of using $\mathrm{ZnO}$ over $\mathrm{TiO}_{2}$ are its direct band gap (3.37 eV), higher exciton binding energy $(60 \mathrm{meV})$ compared to $\mathrm{TiO}_{2}(4 \mathrm{meV})$, and higher electron mobility $\left(200 \mathrm{~cm}^{2} \cdot \mathrm{V}^{-1} \cdot \mathrm{s}^{-1}\right)$ over $\mathrm{TiO}_{2}\left(30 \mathrm{~cm}^{2} \cdot \mathrm{V}^{-1} \cdot \mathrm{s}^{-1}\right)$. Nevertheless, the efficiency of the DSSC based on $\mathrm{ZnO}$ nanostructures is still very low [23].

In this study, DSSCs were fabricated using ten different natural dyes extracted from plant seeds. These seeds have no nutritional use, are cheap, and popularly grown in Palestine. The UV-Vis absorption spectra of the extracted dyes were investigated. The photoelectrochemical properties of the fabricated DSSCs using these extracts as sensitizers were studied. Some of the extracted dyes were anchored on another type of metal oxide to make a comparison for the usefulness of both the dyes and the metal oxides in the photovoltaic conversion of the DSSCs. Moreover, the effect of sintering procedure of the porous semiconductor thin film layer on the performance of the DSSC was studied.

\section{Experiment}

\subsection{Preparation of natural dye sensitizers}

We collected dry seeds of ten different plants. These seeds were thuja, chelidonium majus, ilex paraguariensis, oak, lactuca sativa, rapa, lepidium sativum, corchorus olitorius, allium cepa (onion), and apium graveolens (celery). The seeds were washed with distilled water, dried at $60{ }^{\circ} \mathrm{C}$, and then grinded into fine powders. $10 \mathrm{ml}$ of ethanol (as a solvent) were added to $1 \mathrm{~g}$ of the prepared powder. The mixture was filtered after $24 \mathrm{~h}$, then concentrated at $60{ }^{\circ} \mathrm{C}$. After that the extracted dyes were ready to use.

\subsection{Preparation of semiconducting films}

FTO conductive glass sheets with sheet resistance of $15 \Omega / \mathrm{cm}^{2}$ and transmission $>80 \%$
(Xinyan Technology Ltd., Hong Kong) were first cleaned using an ultrasonic bath for $15 \mathrm{~min}$, rinsed with water and ethanol, and then dried. Plastic adhesive tape was fixed on three sides of the conductive glass sheet to reduce the cell area to $0.25 \mathrm{~cm}^{2}$. $\mathrm{TiO}_{2}$ homogeneous paste was prepared by grinding $50 \mathrm{mg}$ of $\mathrm{TiO}_{2}$ nanopowder with the size of 10 to $25 \mathrm{~nm}$ (US Research Nanomaterial, Inc., USA) with $50 \mathrm{mg}$ of polyethylene glycol in a mortar for half an hour until a homogeneous paste was obtained. The paste was spread onto the conductive glass by using a glass rod to form a thin semiconducting film. The films were then dried for $30 \mathrm{~min}$ at $60{ }^{\circ} \mathrm{C}$. Finally, the films were sintered at $450{ }^{\circ} \mathrm{C}$ for $30 \mathrm{~min}$ to ensure that the particles of the $\mathrm{TiO}_{2}$ thin film were electronically interconnected. After cooling to a temperature of $60{ }^{\circ} \mathrm{C}$, the conductive glass covered with $\mathrm{TiO}_{2}$ film was immersed in the alcohol solution of a natural dye sensitizer for $24 \mathrm{~h}$ to anchor the dye on $\mathrm{TiO}_{2}$ porous film adequately.

The current work has been divided into three parts. In the first part, the performance of the DSSCs was investigated using $\mathrm{TiO}_{2}$ as a semiconducting material with all extracts. In the second part, the performance of the DSSCs was investigated with the highest response cells found in part A, using $\mathrm{ZnO}$ nanoparticles instead of $\mathrm{TiO}_{2}$. Part three was devoted to exploring the performance of the cells when the semiconducting layer was sintered continuously to $450{ }^{\circ} \mathrm{C}$ and when the sintering process was performed gradually to the same degree in three steps.

\subsection{Assembling of DSSC}

The $\mathrm{TiO}_{2}$ porous film electrode (anode) and a conductive glass sheet plated with platinum (cathode, prepared by electrodeposition) were sandwiched to assemble the DSSC. The space between the two electrodes was filled with a liquid electrolyte solution composed of $2 \mathrm{ml}$ acetonitrile $(\mathrm{ACN}), 8 \mathrm{ml}$ propylene carbonate (p-carbonate), $0.668 \mathrm{~g}(\mathrm{KI})$, and $0.0634 \mathrm{~g}\left(\mathrm{I}_{2}\right)$. Then, the two electrodes were clipped together to form a solar cell.

\subsection{Measurements}

The dye solutions absorption spectra were measured in a wavelength range of 350 to $800 \mathrm{~nm}$ 
using a UV-Vis spectrophotometer (Thermoline Genesys 6). The photocurrent-voltage (I-V) curve was measured under simulated sunlight (AM1.5, $100 \mathrm{~mW} \cdot \mathrm{cm}^{-2}$ ) using National Instruments data acquisition card (USB NI 6251) in combination of a Labview program. According to the I-V curves, the fill factor $(\mathrm{FF})$ was calculated as:

$$
F F=\frac{I_{m} V_{m}}{I_{s c} V_{o c}}
$$

where $\mathrm{I}_{\mathrm{m}}$ and $\mathrm{V}_{\mathrm{m}}$ are the photocurrent and photovoltage for maximum power output $\left(\mathrm{P}_{\mathrm{m}}\right), \mathrm{I}_{\mathrm{sc}}$ and $\mathrm{V}_{\mathrm{oc}}$ are the short-circuit photocurrent and opencircuit photovoltage, respectively.

The overall energy conversion efficiency $(\eta)$ is defined as:

$$
\eta=\frac{F F I_{s c} V_{o c}}{P_{i n}}
$$

where $P_{\text {in }}$ is the power of incident light.

\section{Results and discussions}

Fig. 1 shows the absorption spectra of lepidium sativum (A) and apium graveolens (B) extracts using ethyl alcohol as a solvent. As can be seen from the figure, lepidium sativum extract has an absorption peak in the visible region at $670 \mathrm{~nm}$, whereas apium graveolens extract shows some small peaks between 650 to $800 \mathrm{~nm}$ with the most obvious one at $765 \mathrm{~nm}$.

The measurements of I-V characteristic curves of ten DSSCs dyed with different seed extracts have been carried out under the illumination with white light of intensity of $100 \mathrm{~mW} / \mathrm{cm}^{2}$ from a high pressure mercury arc lamp. The I-V characteristic curves for DSSCs sensitized with rapa, lepidium sativum, allium cepa (onion), and apium graveolens are shown in Fig. 2. The DSSC output power has been calculated as $\mathrm{P}=\mathrm{I} \cdot \mathrm{V}$ using the I-V data corresponding to each cell. Fig. 3 represents the output power plotted as a function of voltage. The photocurrent $\left(\mathrm{I}_{\mathrm{m}}\right)$ and photovoltage $\left(\mathrm{V}_{\mathrm{m}}\right)$ corresponding to the maximum power point $\left(\mathrm{P}_{\mathrm{m}}\right)$ were then obtained for each cell from the P-V curve. The values of the fill factor and the cell conversion efficiency were then calculated using equations 1 and 2. All these results were summarized in
Table 1. It is clear from the table that the DSSCs sensitized with rapa, allium cepa (onion) and lactuca sativa have the highest short circuit current densities with values of $2.9,2.6$, and $2.5 \mathrm{~mA} / \mathrm{cm}^{2}$, respectively. The dye extracted from chelidonium majus has the lowest value of $0.345 \mathrm{~mA} / \mathrm{cm}^{2}$. On the other hand, the cell sensitized with the extract of lepidium sativum has the maximum open circuit voltage of $0.65 \mathrm{~V}$, whereas the minimum value for $V_{\mathrm{oc}}$ is $0.49 \mathrm{~V}$ for the cells dyed with thuja and chelidonium majus. The fill factor of the fabricated cells changes in the range of 0.21 to 0.53 . The highest fill factor was obtained for the DSSC sensitized with the extract of allium cepa (onion). Moreover, the dye with the maximum fill factor had the highest output power and conversion efficiency value of $0.875 \%$. These results are similar to those of the DSSCs sensitized by other natural dyes in previous works [11-19]. Moreover, Table 1 shows the photoelectrochemical parameters of a DSSC sensitized with $\mathrm{Ru}$ complex cis-dicyano-bis(2,2'-bipyridyl4,4'-dicarboxylic acid) ruthenium(II), Ruthenizer 505, (Solaronix, Switzerland), which is widely used in DSSCs. The $\mathrm{V}_{\mathrm{oc}}$ and the fill factors of the DSSCs sensitized with the extracts of rapa, lepidium sativum, allium cepa (onion) and apium graveolens are very close to that of the DSSC sensitized by $\mathrm{Ru}$ complex. The main difference between the results of the cells fabricated with natural dyes in the current work, compared to that sensitized by $\mathrm{Ru}$ complex, is the low efficiency, which is due to the low short circuit current.

$\mathrm{TiO}_{2}$ is recognized as the most common electrode material for DSSCs because the $\mathrm{TiO}_{2}$-based cells generally have relatively high-energy conversion efficiencies. However, many kinds of metal oxide semiconductors have also been applied in the fabrication of DSSCs. Among them, $\mathrm{ZnO}$ is widely investigated in terms of transport of the injected electrons.

In the second part of this work we investigated the performance of some of our dyes with $\mathrm{ZnO}$ semiconducting films instead of $\mathrm{TiO}_{2} . \mathrm{ZnO}$ electrodes were prepared from $\mathrm{ZnO}$ powder with an approximate nanoparticle size of $50 \mathrm{~nm}$ (MTI Corporation, USA). DSSCs with $\mathrm{ZnO}$ thin film 
Table 1. The photoelectrochemical parameters of the DSSCs sensitized by dyes extracted from plant seeds.

\begin{tabular}{ccccccc}
\hline Dye & $\begin{array}{c}J_{s c} \\
\left(\mathrm{~mA} / \mathrm{cm}^{2}\right)\end{array}$ & $\begin{array}{c}V_{o c} \\
(\mathrm{~V})\end{array}$ & $\begin{array}{c}J_{m} \\
\left(\mathrm{~mA} / \mathrm{cm}^{2}\right)\end{array}$ & $\begin{array}{c}V_{m} \\
(\mathrm{~V})\end{array}$ & $\begin{array}{c}F F \\
\%\end{array}$ & $\begin{array}{c}\eta \\
\%\end{array}$ \\
\hline \hline Thuja & 0.81 & 0.49 & 0.48 & 0.313 & 38 & 0.15 \\
Chelidoniumma & 0.345 & 0.49 & 0.22 & 0.281 & 37 & 0.062 \\
Llexpuraguariensis & 0.7 & 0.57 & 0.357 & 0.364 & 33 & 0.13 \\
Quercus (Oak) & 1.77 & 0.53 & 1.1 & 0.345 & 40 & 0.38 \\
Lactuca sativa & 2.5 & 0.59 & 1.55 & 0.42 & 21 & 0.31 \\
Rapa & 2.9 & 0.63 & 1.9 & 0.45 & 47 & 0.86 \\
Lepidium sativum & 1.72 & 0.65 & 1.2 & 0.48 & 51 & 0.575 \\
Corchorus olitorius & 0.55 & 0.54 & 0.4 & 0.3 & 40 & 0.12 \\
Allium cepa(Onion) & 2.6 & 0.635 & 1.95 & 0.45 & 53 & 0.875 \\
Apium graveolens & 1.8 & 0.635 & 1.14 & 0.43 & 43 & 0.49 \\
Ruthenium & 12 & 0.621 & 9.78 & 0.373 & 49 & 3.65 \\
\hline
\end{tabular}

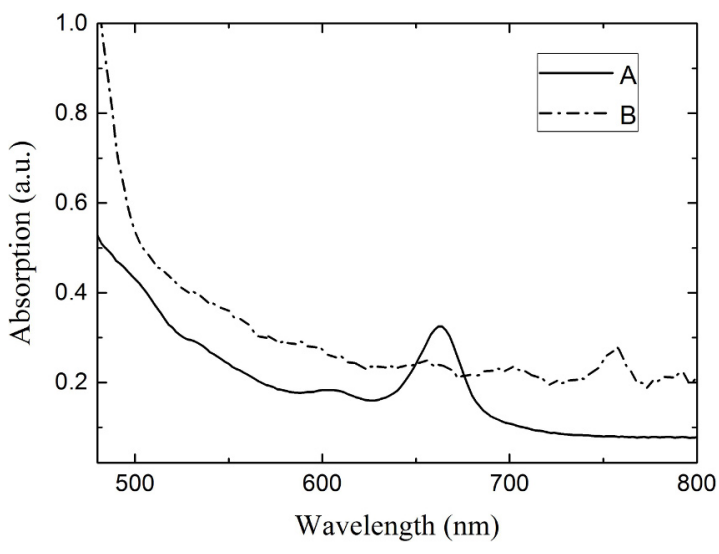

Fig. 1. Absorption spectra of the extracts of lepidium sativum (A) and apium graveolens (B) using ethyl alcohol as solvent.

semiconducting layer were prepared using the same procedure as described above. Three extracts were chosen (rapa, lepidium sativum and allium cepa) as sensitizing dyes. Fig. 4 illustrates the I$\mathrm{V}$ characteristic curves of these DSSCs under illumination with light intensity of $100 \mathrm{~mW} / \mathrm{cm}^{2}$. The photoelectrochemical parameters of these cells are summarized in Table 2. It is clear that the cell parameters are much less than those listed in Table 1 for the same extracts. As Table 2 shows, $\mathrm{J}_{\mathrm{sc}}$ changes in the range of 0.5 to $1.53 \mathrm{~mA} / \mathrm{cm}^{2}, \mathrm{~V}_{\text {oc }}$ varies from 0.33 to $0.38 \mathrm{~V}$, the lowest value of the fill factor is 0.21 , but the highest one is 0.33 , and the

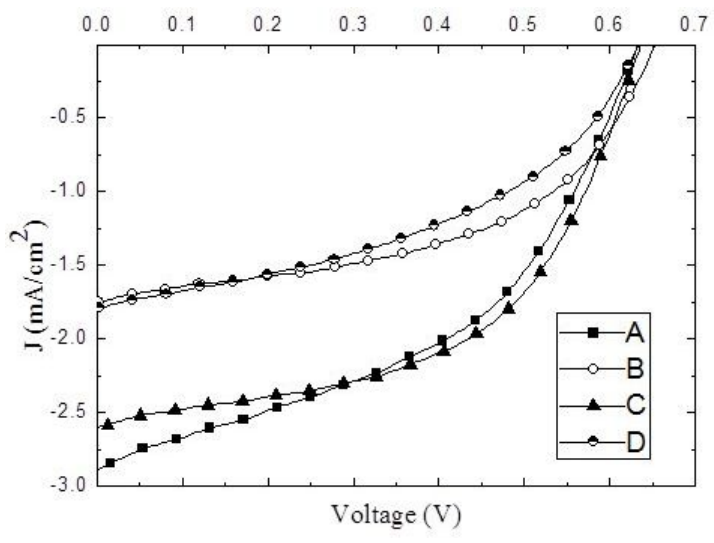

Fig. 2. I-V curves for the DSSC sensitized by rapa (A), lepidium sativum (B), allium cepa (C), and apium graveolens (D) at light intensity $100 \mathrm{~mW} / \mathrm{cm}^{2}$.

conversion efficiency changes from 0.035 to $0.19 \%$. If you look closer at the results of the three chosen extracts, the DSSC sensitized with rapa exhibits a conversion efficiency of $0.86 \%$ when using $\mathrm{TiO}_{2}$ as a semiconducting layer and $0.035 \%$ when using $\mathrm{ZnO}$. Similarly, when using lepidium sativum as a sensitizing dye, the conversion efficiency of $0.575 \%$ obtained with $\mathrm{TiO}_{2}$ has declined to $0.07 \%$ with $\mathrm{ZnO}$. Finally, the conversion efficiency of the DSSC sensitized with allium cepa decreased from $0.875 \%$ to $0.19 \%$. In agreement with many previous works [3], DSSCs fabricated with $\mathrm{TiO}_{2}$ as a semiconducting layer exhibit much 


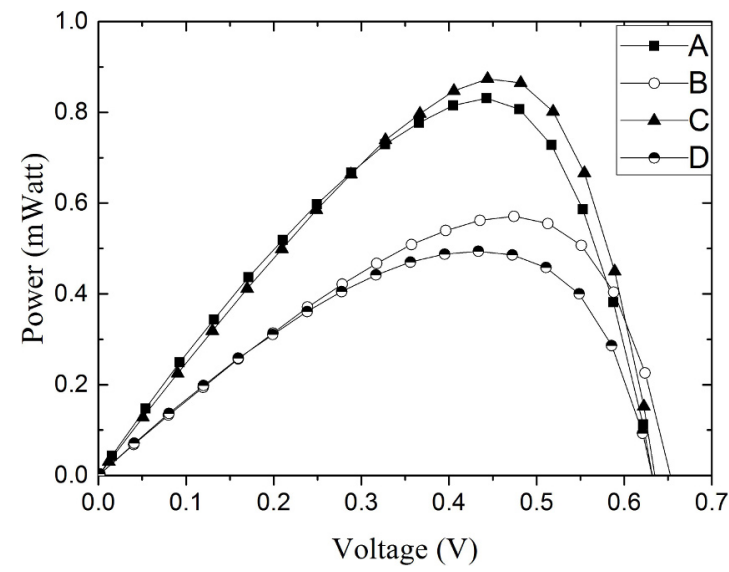

Fig. 3. P-V curves of the DSSC sensitized by rapa (A), lepidium sativum (B), allium cepa (C), and apium graveolens (D).

better performance in photoelectric conversion of light compared to those employing $\mathrm{ZnO}$ as a semiconductor. One of the reasons of the poor response of $\mathrm{ZnO}$ cells is the lower open-circuit voltage of $\mathrm{ZnO}$-based cells compared to that of $\mathrm{TiO}_{2}$-based cells. The difference in $\mathrm{V}_{\mathrm{oc}}$ is possibly due to a recombination, namely, capturing the electrons photogenerated in the conduction band of the metal oxide semiconductor layers by oxidized species in an electrolyte.

Comparative studies show that although $\mathrm{TiO}_{2}$ adsorb less dye molecules, they could effectively retard charge recombination and achieve longer electron lifetime than $\mathrm{ZnO}$; as a result, the DSSCs composed of $\mathrm{TiO}_{2}$ exhibit higher performance than those of $\mathrm{ZnO}$.

The sintering process plays a significant role in improving the efficiency of charge collection by promoting both more rapid electron transport and slower charge recombination. This affects the electrically connected network of $\mathrm{TiO}_{2}$ particles [24]. This condition improves $\mathrm{TiO}_{2}$ performance as an electron transport material. Besides electron transporting, the porosity of $\mathrm{TiO}_{2}$ nanoparticles offers large surface area for dye adsorption. Particularly, this affects the number of dye molecules that can be adsorbed [25-28]. At a certain level of porosity, $\mathrm{TiO}_{2}$ particles can adsorb the maximum amount of dye which affects the performance of the DSSC.

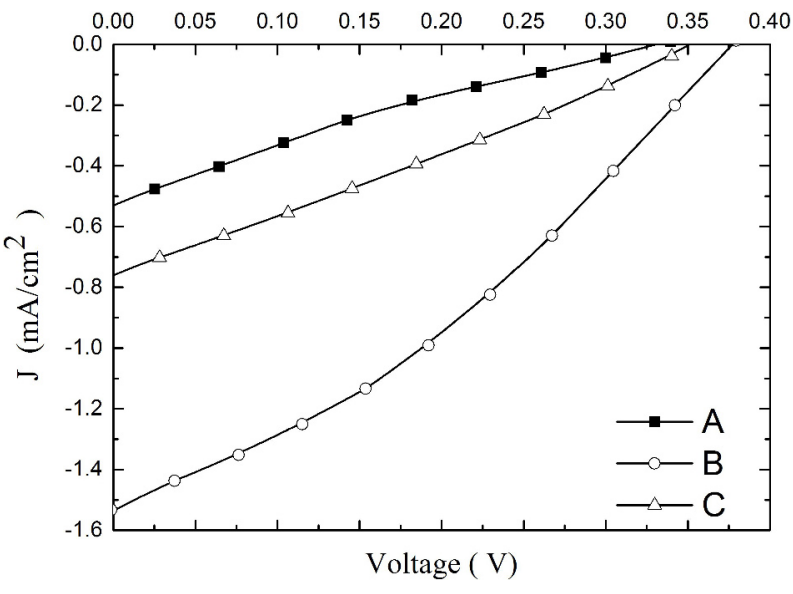

Fig. 4. I-V curves of the DSSCs sensitized by using $\mathrm{ZnO}$ nanoparticles as semiconductor and sensitized by rapa (A), lepidium sativum (B), and allium cepa $(C)$ sensitizing dyes.

In the last part of this work, the effect of sintering process on the characteristics of $\mathrm{TiO}_{2}$-based DSSC is presented. It is well known that semiconducting film porosity is related to sintering duration and temperature, which affects the photocurrent density and the amount of adsorbed dye.

FTO substrates covered with a $\mathrm{TiO}_{2}$ film were sintered in a furnace by raising the temperature gradually from $60{ }^{\circ} \mathrm{C}$ to $180{ }^{\circ} \mathrm{C}$, the sample was stabilized at $180{ }^{\circ} \mathrm{C}$ for $10 \mathrm{~min}$., then from $180{ }^{\circ} \mathrm{C}$ to $320{ }^{\circ} \mathrm{C}$, the sample was stabilized at $320{ }^{\circ} \mathrm{C}$ for $10 \mathrm{~min}$., and finally the temperature was raised to $450{ }^{\circ} \mathrm{C}$ for another $10 \mathrm{~min}$. We have called this process gradual sintering. Other samples were sintered continuously from $60{ }^{\circ} \mathrm{C}$ to $450{ }^{\circ} \mathrm{C}$ for $30 \mathrm{~min}$. This sintering process has been called continuous sintering. The same procedure of cooling and immersing in the dye was followed for gradual and continuous sintered samples. Four dyes were used in this investigation. Two of them, i.e. rapa and allium cepa, were natural, whereas the others included two different Ru-complexes: cis-dicyano-bis(2,2'-bipyridyl4,4'-dicarboxylic acid) ruthenium(II) Ruthenizer 505 (Ru1) and cis-bis(isothiocyanato) bis(2,2 bipyridine-404-dicarboxylate) Ruthenium(II)957 $\mathrm{N}_{3}$ (Ru2). Each dye was used with a gradually and a continuously sintered samples. 
Table 2. Photoelectrochemical parameters of the DSSCs sensitized by various natural dyes with $\mathrm{ZnO}$ semiconducting layer.

\begin{tabular}{ccccccc}
\hline Dye & $\begin{array}{c}J_{s c} \\
\left(\mathrm{~mA} / \mathrm{cm}^{2}\right)\end{array}$ & $\begin{array}{c}V_{o c} \\
(\mathrm{~V})\end{array}$ & $\begin{array}{c}J_{m} \\
\left(\mathrm{~mA} / \mathrm{cm}^{2}\right)\end{array}$ & $\begin{array}{c}V_{m} \\
(\mathrm{~V})\end{array}$ & $\begin{array}{c}F F \\
\%\end{array}$ & $\begin{array}{c}\eta \\
\%\end{array}$ \\
\hline \hline Rapa & 0.50 & 0.33 & 0.25 & 0.14 & 21 & 0.035 \\
Lepidium sativum & 0.75 & 0.35 & 0.39 & 0.18 & 27 & 0.07 \\
Allium cepa & 1.53 & 0.38 & 1.00 & 0.19 & 33 & 0.19 \\
\hline
\end{tabular}

Fig. 5 shows the I-V characteristic curves for four DSSCs dyed with Ru1 and Ru2 complexes. It is clear that the gradually sintered cells for both dyes show a considerable enhancement in the short circuit current as well as the efficiency compared to the continuously sintered ones. The $\mathrm{J}_{\mathrm{sc}}$ increases from 11.38 to $20.23 \mathrm{~mA} / \mathrm{cm}^{2}$ for DSSCs sensitized with Ru1 and from 7.48 to $17.08 \mathrm{~mA} / \mathrm{cm}^{2}$ for those sensitized with Ru2. Moreover, the efficiency of these cells has enhanced from $3.5 \%$ to $5.3 \%$ for Ru1 dye and from $2.7 \%$ to $5.5 \%$ for Ru2 due to the gradual sintering. In a similar manner, Fig. 6 shows the results obtained for the rapa and allium cepa as sensitizing dyes for DSSCs sintered gradually and continuously. In analogy to the results obtained in case of Ru-complexes, the curves show an enhancement from 2.88 to $3.43 \mathrm{~mA} / \mathrm{cm}^{2}$, for the cells sensitized with rapa dye, and from 2.39 to $2.69 \mathrm{~mA} / \mathrm{cm}^{2}$ for the cells sensitized with allium cepa. The photoelectrochemical parameters of these cells are summarized in Table 3.

This improvement in the short circuit current of the gradually sintered cells can be attributed to making the thin film layer more homogeneous with less cracks in the step sintering process. Rapid and continuous sintering led to cracking of the films that could be easily peeled from the FTO substrate.

\section{Conclusion}

Dye sensitized solar cells were fabricated using two semiconducting materials: $\mathrm{TiO}_{2}$ and $\mathrm{ZnO}$. Natural extracts from plant seeds were used to sensitize these cells. The extracted dyes were characterized by UV-Vis absorption spectroscopy. The $\mathrm{I}-\mathrm{V}$ characteristic curves were measured and the

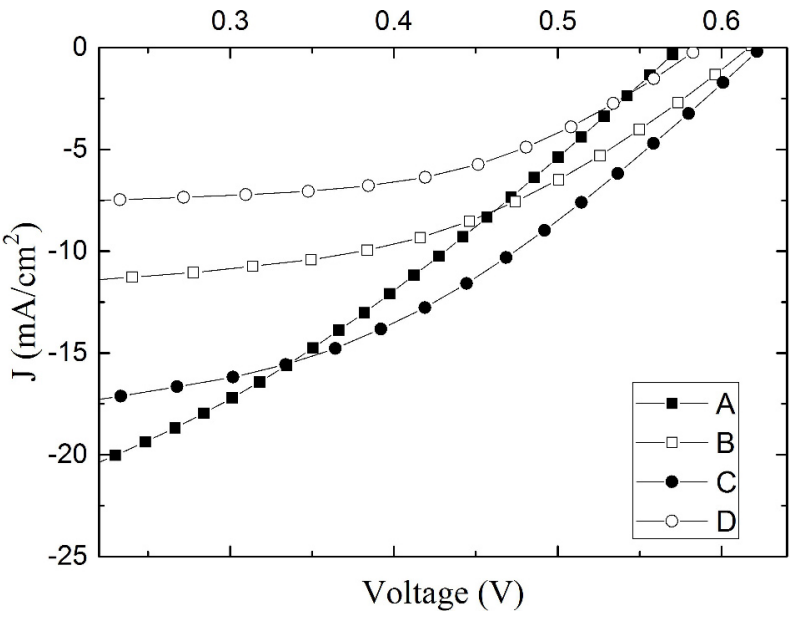

Fig. 5. I-V curves of DSSCs sensitized by Ru1 (A and $\mathrm{B}$ ) when $\mathrm{TiO}_{2}$ film was sintered gradually (A) and continuously (B). The curves $\mathrm{C}$ and $\mathrm{D}$ represent DSSCs sensitized by $\mathrm{Ru} 2$ when $\mathrm{TiO}_{2}$ film was sintered gradually (C) and continuously (D).

photoelectrochemical properties were determined. The highest conversion efficiency of $0.875 \%$ was obtained for the DSSC fabricated using $\mathrm{TiO}_{2}$ semiconducting layer and sensitized by allium cepa extract. The open circuit voltage of the DSSCs sensitized with the extracts of rapa, lepidium sativum, allium cepa, and apium graveolens are very close to that of the cells sensitized by ruthenium complex. It has been confirmed that when using $\mathrm{TiO}_{2}$ as a semiconducting layer, the cells exhibit much better performance in photoelectric conversion of light than the cells using $\mathrm{ZnO}$. Moreover, it was found that the sintering procedure affected the response of the cell. The short circuit current density of the DSSC was found to significantly enhance when the $\mathrm{TiO}_{2}$ semiconducting layer was sintered gradually. 
Table 3. Photoelectrochemical parameters of the DSSCs when $\mathrm{TiO}_{2}$ film was sintered gradually and continuously.

\begin{tabular}{ccccccc}
\hline Dye & Sintering process & $\begin{array}{c}J_{s c} \\
\left(\mathrm{~mA} / \mathrm{cm}^{2}\right)\end{array}$ & $\begin{array}{c}V_{o c} \\
(\mathrm{~V})\end{array}$ & $\begin{array}{c}J_{m} \\
\left(\mathrm{~mA} / \mathrm{cm}^{2}\right)\end{array}$ & $\begin{array}{c}V_{m} \\
\mathrm{r}(\mathrm{V})\end{array}$ & $\begin{array}{c}\eta \\
\%\end{array}$ \\
\hline \hline \multirow{2}{*}{ Rapa } & gradual & 3.43 & 0.633 & 2.26 & 0.442 & 0.99 \\
\cline { 2 - 7 } & continuous & 2.88 & 0.629 & 1.89 & 0.442 & 0.82 \\
\hline \multirow{2}{*}{ Allium cepa } & gradual & 2.69 & 0.610 & 1.75 & 0.427 & 0.75 \\
\cline { 2 - 7 } & continuous & 2.39 & 0.605 & 1.56 & 0.439 & 0.70 \\
\hline \multirow{2}{*}{ Ru1 } & gradual & 20.23 & 0.571 & 16.14 & 0.321 & 5.3 \\
\cline { 2 - 7 } & continuous & 11.38 & 0.615 & 9.8 & 0.372 & 3.5 \\
\hline \multirow{2}{*}{ Ru2 } & gradual & 17.08 & 0.625 & 13.8 & 0.417 & 5.5 \\
\cline { 2 - 7 } & continuous & 7.48 & 0.583 & 6.25 & 0.417 & 2.7 \\
\hline
\end{tabular}

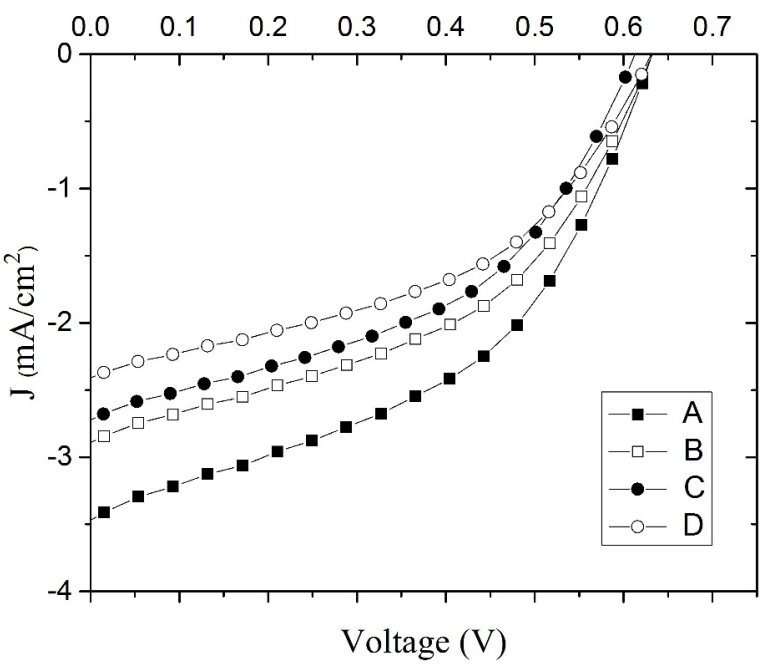

Fig. 6. I-V curves for DSSCs sensitized by rapa (A and B) when $\mathrm{TiO}_{2}$ film was sintered gradually (A) and continuously (B). The curves $\mathrm{C}$ and $\mathrm{D}$ represent DSSCs sensitized by allium cepa when $\mathrm{TiO}_{2}$ film was sintered gradually $(\mathrm{C})$ and continuously (D).

\section{References}

[1] O’Regan B., Gratzel M., Nature, 353 (1991), 737.

[2] Gratzel M., J. Photoch. Photobio. C, 4 (2003), 145.

[3] Longyue Z., Songyuan D., Weiwei X., Konggia W., Plasma Sci. Technol., 18 (2006), 172.

[4] Odobel F., Blart E., Lagrée M., Villieras M., Boujtita H., El Murr N., Caramori S., BigNOZZI C.A., J. Mater. Chem., 13 (2003), 502.

[5] Abdel-Latif M., El-Agez T., Taya S., Batniui A., El-Ghamri H., Mater. Sci. Appl., 4 (2013), 516.

[6] Batniji A., Morjan R., Abdel-Latif M., ElAgez T., Taya S., El-Ghamri H., Turk. J. Phys., 38 (2014), 86.
[7] Isiam A., Sugihara H., Hara K., Singh L., Katoh R., Yanagida M., Takahashi Y., Murata S., ARAKAWA H., Inorg. Chem., 40 (2001), 5371.

[8] RehM J.M., MCLendon G.L., Nagasawa Y., Yoshihara K., Moser J., Grätzel M., J. Phys. Chem., 100 (1996), 9577.

[9] Zhang D., Lanier S., Downing J., Avent L., Lumc J., McHale J., J. Photoch. Photobio. A, 195 (2008), 72.

[10] Hao S., Wu J., Huang Y., Lin J., Sol. Energy, 80 (2006), 209.

[11] Wu G., Shen V., Gu F., Lu H., XIE Y., Opt. Soc. Am., 310 (2009), 4256.

[12] Taya S., El-Agez T., El-Ghamri H., AbDElLATIF M., Int. J. Mater. Sci. Appl., 2 (2013), 37.

[13] Zhou H., Wu L., Gao Y., Ma T., J. Photoch. Photobio. A, 219 ( 2011), 188.

[14] Wongcharee K., Meeyoo V., Chavadej S., Sol. Energ. Mat. Sol. C, 91 ( 2007), 566.

[15] Roy M., Balraju P., Kumar M., Sharma G., Sol. Energ. Mat. Sol. C, 92 (2008), 909.

[16] Calogero G., Marco G., Sol. Energ. Mat. Sol. C, 92 (2008), 1341.

[17] Lin T., Lin J., Tsai S., LeE J., TING CH., The $31^{\text {st }}$ National Conference on Theoretical and Applied Mechanics, December 21 - 22, ISU, Kaohsiung, Taiwan, R.O.C., 2007.

[18] Ito S., Saitou T., Imahori H., Ueharad H., HASEgawad N., Energ. Environ. Sci., 3 (2010), 905.

[19] El-Agez T., El Tayyan A., Al-Kahlout A., Taya S., ABDel-LATIF S., Int. J. Mater. Chem., 2 (2012), 105.

[20] Dai Q., Rabani J., J. Photoch. Photobio. A, 26 (2002), 421.

[21] Tennakone K., Kumarasinghe A., Kumara G., Wijayantha K., Sirimanne P., J. Photoch. Photobio., 108 (1997), 193.

[22] Bmer C., Boschloo G., Hagfeld A., J. Phys. Chem. B, 105 (2001), 5585.

[23] IKegami M., OZEKi M., KiJitori Y., MiYASAKA T., Electrochemistry, 76 (2008), 140. 
[24] Winantyo R., Zulfia A., Poespawati N., HarTANTO D., J. Mater. Sci. Eng. A, 2 (2012), 232.

[25] Meen T., Water W., Chen W., Chao S., Huang C., J. Phys. Chem. Solids, 70 (2009), 472.

[26] Nakade S., Saito Y., Kubo W., Kitamura T., Wada Y. Yanagida S., J. Phys. Chem., 107 (2003), 8607.
[27] Saito Y., Kambe S., Kitamura T., Wada Y. YANAGIDA S., Sol. Energ. Mat. Sol. C., 83 (2004), 50.

[28] Hamadanian M., JABbaRi V., $5^{\text {th }}$ SASTech 2011, Khavaran Higher-education Institute, Mashhad, Iran, 12 - 14 May, 2011.

Received 2013-10-25

Accepted 2014-07-21 